\title{
Z PROBLEMATYKI ZBIERANIA I MAGAZYNOWANIA ODPADÓW
}

\section{SELECTED PROBLEMS OF WASTE COLLECTION AND STORAGE}

\section{STRESZCZENIE}

Artykuł dotyczy wybranych problemów dotyczących zbierania i magazynowania odpadów. Omówiono pojęcia „zbierania” i „magazynowania" odpadów. Naświetlono w nim problematykę wydawania zezwoleń na zbieranie odpadów w aspekcie elementów wniosku składanego przez podmiot wnioskujący o zezwolenie. Skupiono się też na fragmencie problematyki cofnięcia zezwolenia. Wniosek płynący $\mathrm{z}$ opracowania jest taki, że stosowanie $\mathrm{w}$ praktyce przepisów ustawy o odpadach powoduje wiele wątpliwości. Podstawowe czynności $\mathrm{w}$ zakresie gospodarowania odpadami, jakimi są zbieranie i magazy-

* Doktor nauk prawnych, adiunkt w Katedrze Prawa Cywilnego Europejskiej Wyższej Szkoły Prawa i Administracji, Kancelaria Radców Prawnych s.c. dr K. Szuma, H. Zambrowicz-Rybarczyk w Poznaniu. 
nowanie są niejednoznacznie rozumiane przez organy i przedsiębiorców, wywołują wiele wątpliwości interpretacyjnych. Niektóre z tych wątpliwości zostały przedstawione i w możliwym zakresie wyjaśnione.

\section{Słowa kluczowe}

Zbieranie odpadów, magazynowanie odpadów, zezwolenie na zbieranie odpadów, cofnięcie zezwolenia.

\section{ABSTRACT}

This article concerns selected problems of waste collection and storage. The definitions of waste "collecting" and "storing" were analysed. The problems of filling an application and issuing waste collection permits were explained. Attention also was focused on some permission withdrawal issues. The article leads to conclusion that application of Waste Act causes many problems. Even routine waste operations, such as waste collecting and storing, cause interpretation problems and are assessed divergently by administrative organs and entrepreneurs. Some of these questions are presented and explained.

\section{Keywords}

Waste collection and storage, permission withdrawal issues.

Interpretacja pojęcia zbierania i magazynowania odpadów w praktyce powoduje wiele problemów. Przedsiębiorcy różnie interpretują te pojęcia, jak również organy w praktyce stosują różną wykładnię wskazanych definicji. Przedmiotem opracowania będzie fragment problematyki związanej z procesem zbierania i magazynowania odpadów. Poruszone zostaną zagadnienia interpretacji wskazanych pojęć oraz kwestie związane z wydaniem, a konkretnie z elementami wniosku o wydanie zezwolenia na zbieranie odpadów, jak również uwaga zostanie zwrócona na tematykę cofnięcia zezwolenia na zbieranie. Wskazany wycinek zagadnień ma doniosłe znaczenie nie tylko teoretyczne, ale przede wszystkim praktyczne. Przepisy regulujące wspomniane instytucje powodują wiele wątpliwości interpretacyjnych. W efekcie przedsiębiorcy borykają się z licznymi problemami, 3/2012 których rozwiązanie pochłania ich czas, a także utrudnia wy- 
konywanie działalności. Również organy prowadzące postępowania o wydanie zezwolenia na zbieranie odpadów czy o jego cofnięcie często są uwikłane w trudnościach interpretacyjnych, co skutkuje często skutecznym zaskarżeniem ich rozstrzygnięć. Problemu nie rozwiązuje sposób legislacji. W efekcie wprowadzonych licznych pojęć niedookreślonych, z pozoru nie budzących wątpliwości sprawy mogą nabrać charakteru bardzo skomplikowanego.

W pierwszej kolejności omówione zostanie pojęcie „zbierania odpadów". Biorąc pod uwagę definicję zbierania odpadów zawartą w ustawie z dnia 27 kwietnia 2001 r. o odpadach ${ }^{1}$ stwierdzić trzeba, że „zbieranie odpadów”, zgodnie z dyspozycją ustawodawcy, to „(...)każde działanie (...) które ma na celu przygotowanie ich do transportu (...)". Nie można więc wykluczyć, że to „każde działanie, które ma na celu przygotowania ich do transportu"2 nie może być pozostawianiem tych odpadów luzem, np. jak stanowi ustawodawca, w celu „(...)umieszczenia ich w pojemnikach”. Użycie przez ustawodawcę zwrotu „każde działanie" oznacza, że nie można wyciągać negatywnych konsekwencji w stosunku do podmiotu, który z różnych powodów, $\mathrm{w}$ trakcie procesu zbierania odpadów umieścił je chwilowo np. luzem na zabezpieczonym placu w celu natychmiastowego umieszczenia ich w pojemnikach. Ustawodawca stanowi, że przez pojęcie „zbierania” rozumie się „każde działanie, w szczególności umieszczanie w pojemnikach, segregowanie i magazynowanie odpadów, które ma na celu przygotowanie ich do transportu do miejsc odzysku lub unieszkodliwiania". W definicji ustawodawca użył zwrotu „w szczególności”, co oznacza, że zbieranie może, a nie musi być „umieszczaniem w pojemnikach”. Katalog czynności „zbierania” ustawodawca pozostawił otwarty. Ustawodawca zamieścił definicje legalne niektórych pojęć w ustawie ze względu na chęć uniknięcia ewentualnych zarzutów kierowanych pod adresem podmiotów gospodarują-

1 Tj. Dz. U. z 2010 r. Nr 185, poz. 1243 ze zm., dalej cyt.: ustawa o odpadach.

Art. 3 ust. 3 pkt 23 ustawy o odpadach. 
cych odpadami, a formułowanych w związku z potocznym rozumieniem tych pojęć.

Poza tym należy też wskazać, że to „każde działanie” powinno mieć na celu przygotowanie odpadów do transportu, ale nie do transportu jakiegokolwiek, a transportu do miejsc odzysku lub unieszkodliwiania. Zbieranie odpadów jest więc jedną z czynności tworzących łańcuch postępowania z odpadami, które po tym, jak zostaną zebrane, są następnie przekazywane do:

- odzysku polegającego na podejmowaniu wszelkich działań, niestwarzających zagrożenia dla życia, zdrowia ludzi lub dla środowiska, polegających na wykorzystaniu odpadów w całości lub w części, lub prowadzących do odzyskania z odpadów substancji, materiałów lub energii i ich wykorzystania, określonych w załącznikunr $5^{3}$ do ustawy ${ }^{4}$ lub/i

- unieszkodliwiania polegającego na poddaniu odpadów procesom przekształceń biologicznych, fizycznych lub chemicznych określonych w załącznikunr $6^{5}$ do ustawy w celu doprowadzenia ich do stanu, który nie stwarza zagrożenia dla życia, zdrowia ludzi lub dla środowiska.

Warto wskazać na stanowisko przedstawicieli doktryny w tym aspekcie. Po pierwsze wskazuje się, że pojęcie „zbierania" jest pojęciem ujmowanym bardzo szeroko. Innymi słowy, zwrot „zbieranie odpadów” niesie ze sobą szeroką treść w aspekcie możliwości podejmowania faktycznych czynności konstytuujących „zbieranie” w aspekcie prawnym. Zbieraniem

3 Załącznik nr 5 ustawy o odpadach dotyczy procesu odzysku i są to np. wykorzystanie jako paliwa lub innego środka wytwarzania energii; regeneracja lub odzyskiwanie rozpuszczalników; recykling lub regeneracja substancji organicznych, które nie są stosowane jako rozpuszczalniki (włączając kompostowanie i inne biologiczne procesy przekształcania); recykling lub regeneracja metali i związków metali.

4 Art. 3 ust. 3 pkt 9 ustawy o odpadach.

5 Załącznik nr 6 ustawy o odpadach dotyczy procesu unieszkodliwiania odpadów i są to np. składowanie na składowiskach odpadów obojętnych, obróbka w glebie i ziemi (np. biodegradacja odpadów płynnych lub szlamów w glebie i ziemi), składowanie przez głębokie zatłaczanie (np. zatłaczanie odpadów, które można pompować), retencja powierzchniowa (np. umieszczanie odpadów na poletkach osadowych lub lagunach). 
odpadów, zgodnie z art. 3 ust. 3 pkt 23 ustawy o odpadach, jest każde działanie, w szczególności umieszczanie w pojemnikach, segregowanie i magazynowanie odpadów, które ma na celu przygotowanie ich do transportu do miejsc odzysku lub unieszkodliwiania. Podstawową więc cechą „zbierania” jest powiązanie określonych czynności z transportem odpadów ${ }^{6}$.

Wskazać należy, że zbieranie odpadów jest elementem szerszego procesu, jaki jest gospodarowanie odpadami. Przez "gospodarowanie odpadami" rozumie się zbieranie, transport, odzysk i unieszkodliwianie odpadów, w tym również nadzór nad takimi działaniami oraz nad miejscami unieszkodliwiania odpadów ${ }^{7}$.

Ustawodawca reguluje też $\mathrm{w}$ ustawie o odpadach procedurę wydawania zezwolenia na zbieranie i transport odpadów. Przyjęto, że zasadą jest uzyskanie zezwolenia na zbieranie odpadów, a wyjątkiem brak konieczności uzyskania takiego zezwolenia. W art. 28 ustawy o odpadach ustawodawca wskazał m. in. elementy wniosku o wydanie takiego zezwolenia oraz tryb wydawania takiego zezwolenia. Z uwagi na przedmiot opracowania pominięto rozważania dotyczące wydawania zezwolenia na transport uregulowanego w tych samych przepisach, które regulują postępowanie w sprawie wydania decyzji na zbieranie odpadów.

W artykule 28 ust. 4 ustawy o odpadach ustawodawca wskazał elementy wniosku o wydanie zezwolenia na zbieranie odpadów. Wniosek taki powinien zawierać:

1) wyszczególnienie rodzajów odpadów przewidywanych do zbierania lub transportu; w przypadku gdy określenie rodzaju jest niewystarczające do ustalenia zagrożeń, jakie te odpady mogą powodować dla środowiska, właściwy organ może wezwać wnioskodawcę do poda-

6 Zob. M. Górski, Zbieranie i transport odpadów, „Przegląd Komunalny” 2008, nr 2, s. 32 i n. i powoływane przez niego publikacje i pisma urzędowe, np.: Ustawa o odpadach. Komentarz, pod red. J. Jendrośki i J. Jerzmańskiego, Wrocław 2001; W. Radecki, Ustawa o odpadach. Komentarz, Warszawa 2008, a także interpretacje dokonywane przez Ministerstwo Środowiska - pismonr DIOŚ 024/76/7474/03/ID z 14 stycznia 2004 r.

7 Art. 3 ust. 3 pkt 1 ustawy o odpadach. 
nia podstawowego składu chemicznego i właściwości odpadów;

2) oznaczenie obszaru prowadzenia działalności - w przypadku transportu odpadów lub miejsca prowadzenia działalności - w przypadku zbierania odpadów;

3) w przypadku zbierania odpadów wskazanie miejsca i sposobu oraz rodzaju magazynowanych odpadów, a także opis sposobu dalszego zagospodarowania odpadów;

4) wskazanie sposobu i środków transportu odpadów;

5) przedstawienie możliwości technicznych i organizacyjnych pozwalających należycie wykonywać działalność w zakresie zbierania lub transportu odpadów;

6) przewidywany okres wykonywania działalności w zakresie zbierania lub transportu odpadów.

Wyszczególnienie rodzajów odpadów przewidywanych do zbierania powinno polegać na wskazaniu kodów odpadów i ich nazw wraz z określeniem czy dany odpad jest odpadem niebezpiecznym, czy też nie posiada cech kwalifikujących go do odpadów niebezpiecznych. Odpady, o których zbieranie wnioskuje dany podmiot nieoznaczone symbolem „" nie posiadają składników ani właściwości, które kwalifikują je jako odpady niebezpieczne na podstawie załącznikanr $3^{8}$ i załącznikanr $4^{9}$ do ustawy o odpadach. Tym samym odpady te nie powodują zagrożeń dla środowiska wskazujących na konieczność określania ich składu i właściwości na podstawie art. 28 ust. 4 pkt 1 ustawy o odpadach. Odpady nieoznaczone „*" nie mają składników ani właściwości, które powodują albo mogą powodować zagrożenia związane z załadunkiem i rozładunkiem oraz magazynowaniem.

Dodać należy, że każdy wnioskodawca musi mieć na względzie postanowienia art. 7 i 9 oraz 13a ustawy o odpadach i musi przestrzegać zakazów $\mathrm{w}$ nich uregulowanych również

8 Załącznik nr 3 dotyczy składników odpadów, które kwalifikują je jako odpady niebezpieczne.

9 Załącznik nr 4 dotyczy właściwości odpadów, które powodują, że odpady są niebezpieczne. 
w stosunku do odpadów medycznych nie będących odpadami niebezpiecznymi. Istnieje zakaz zbierania pozostałości z sortowania odpadów komunalnych, komunalnych osadów ściekowych, zakaźnych odpadów medycznych, zakaźnych odpadów weterynaryjnych. Dodatkowo ustawodawca wprowadza obostrzenia $\mathrm{w}$ zależności od rodzaju zbieranych odpadów. Stąd np. zgodnie z art. 32 ustawy z dnia 20 stycznia 2005 r. o recyclingu pojazdów wycofanych $\mathrm{z}$ eksploatacji ${ }^{10}$ przedsiębiorca prowadzący punkt zbierania pojazdów jest obowiązany zapewnić bezpieczne dla środowiska i zdrowia ludzi zbieranie pojazdów wycofanych z eksploatacji. Do wniosku o wydanie zezwolenia na prowadzenie działalności w zakresie zbierania odpadów przedsiębiorca prowadzący punkt zbierania pojazdów jest obowiązany dołączyć kopię zawartej z przedsiębiorcą prowadzącym stację demontażu umowy dotyczącej przyjmowania pojazdów zebranych w punkcie zbierania pojazdów.

Ustawodawca w art. 28 ust. 4 pkt 1 ustawy o odpadach przewiduje wezwanie do podania podstawowego składu chemicznego i właściwości odpadów tylko w odniesieniu do zagrożenia, jakie te odpady moga powodować dla środowiska i w przypadku, gdy określenie rodzaju odpadów jest niewystarczające do ustalenia tego zagrożenia. Trzeba przyjąć, że ustawodawca ograniczył wspomniany obowiązek do podania tych danych w stosunku do odpadów niebezpiecznych, bo tylko takie mogą z racji swoich właściwości powodować ewentualne zagrożenia. Należy stwierdzić, że ustawodawca nie określając odpadów jako niebezpieczne, uznał iż nie mają one składników ani właściwości, które powodują zagrożenia wymagające obostrzeń w gospodarowaniu nimi.

Podkreślić trzeba, że żądanie organu przedstawienia właściwości i składu odpadów objętych wnioskiem o zezwolenie na ich zbieranie wymaga wykazania przez organ przesłanki określonej w art. 28 ust. 4 pkt 1 ustawy, a więc wskazania dlaczego w stosunku do odpadów o konkretnych kodach - określenie rodzaju odpadu nie jest wystarczające do ustalenia zagrożenia dla środowiska oraz jakie właściwości i skład chemiczny odpadów

10 Dz. U. z 2005 r. Nr 25, poz. 202 ze zm. 
budzi wątpliwości organu. Jest to konieczne między innymi dlatego, że opracowanie pełnej listy właściwości i składu odpadów wszystkich kodów jest niemalże niemożliwe do wykonania, jeżeli żądanie analizy nie zawiera wskazania jakie właściwości i skład chemiczny ma być identyfikowany. W praktyce, enigmatyczne żądanie organu przedstawienia właściwości i składu odpadów objętych wnioskiem o zezwolenie na ich zbieranie powoduje, że certyfikowane jednostki badawcze zajmujące się chemią odpadową zdecydowanie odmawiają sporządzenia badań odpadów z uwagi na brak zakreślenia przez organ zakresu danych, które powinny być identyfikowane laboratoryjnie.

Podstawowe właściwości zbieranych odpadów sprowadzają się do wykazania, że dany odpad uznany jest za niebezpieczny bądź odpadem niebezpiecznym nie jest. Podstawę do określenia tych właściwości stwarza wydane na podstawie art. 4 ust. 1 pkt 2 ustawy o odpadach rozporządzenie Ministra Środowiska z dnia 13 maja 2004 r. w sprawie warunków, w których uznaje się, że odpady nie są niebezpieczne ${ }^{11}$. Wszystkie zbierane odpady odpowiadają warunkom i posiadają właściwości, które można wykazać na podstawie badań, które prowadzą laboratoria akredytowane lub laboratoria posiadające wdrożony system jakości w zakresie badania właściwości i składników odpadów. Przy czym zakres badań powinien być przez organ konkretnie wskazany, a przedmiot tych badań powinien być kompatybilny z właściwościami i składem chemicznym odpadów, które powinien określić organ prowadzący postępowanie.

Jeśli chodzi o oznaczenie miejsca prowadzenia działalności, polega to na wskazaniu, że odpady zbierane są na terenie bazy w wyznaczonej strefie w miejscu oznaczonym w załączniku graficznym do wniosku. Miejsce takie powinno odpowiadać wymaganiom ochrony środowiska oraz przygotowane powinno być zgodnie z przepisami szczegółowymi w zakresie zbierania odpadów niebezpiecznych i odpadów innych niż niebezpieczne. Miejscem prowadzenia działalności w zakresie zbierania odpadów jest wyodrębniona geodezyjnie nieruchomość, której dane powinny być we wniosku wskazane. 
Jeżeli chodzi o warunki magazynowania wskazać należy, że magazynowanie jako określone przez ustawodawcę czasowe przetrzymywanie lub gromadzenie odpadów przed ich transportem, odzyskiem lub unieszkodliwianiem, oznacza zawsze jeden lub więcej etapów przejściowych w ciągu działań związanych z odpadami: wytworzenie - zebranie - transport - odzysk lub unieszkodliwienie. Wnioskodawca powinien zadeklarować przestrzeganie warunków legalności magazynowania i po uzyskaniu zezwolenia musi tych warunków przestrzegać. Znamiennym jest fakt, że magazynowanie odpowiada i odpowiadać będzie ustawowo określonym warunkom odnoszącym się do miejsca, czasu, celu i podstawy formalnoprawnej ${ }^{12}$.

Ustawodawca w art. 63 ust. 1 ustawy o odpadach warunek dotyczący miejsca określił $\mathrm{w}$ ten sposób, że takie wyznaczenie może mieć postać zezwolenia na prowadzenie działalności w zakresie zbierania lub transportu odpadów. Jeśli chodzi o czas i cel magazynowania, to odpady przeznaczone do odzysku lub unieszkodliwiania, z wyjątkiem składowania, mogą być magazynowane, jeżeli konieczność magazynowania wynika z procesów technologicznych lub organizacyjnych i nie przekracza terminów uzasadnionych zastosowaniem tych procesów, nie dłużej jednak niż przez okres 3 lat $^{13}$. Natomiast odpady przeznaczone do składowania mogą być magazynowane jedynie w celu zebrania odpowiedniej ilości tych odpadów do transportu na składowisko odpadów, nie dłużej jednak niż przez okres 1 roku $^{14}$.

Warunek formalnej podstawy prawnej jest spełniony, jeżeli posiadacz odpadów magazynuje je na terenie, do którego ma tytuł prawny. Definicja tytułu prawnego znajduje się w art. 3 pkt 41 ustawy z dnia 27 kwietnia 2001 r. Prawo ochrony środowiska ${ }^{15}$ i obejmuje: prawo własności, użytkowanie wieczyste, trwały zarząd, ograniczone prawo rzeczowe, stosunek zobowiązaniowy.

12 Zob. W. Radecki, Komentarz do art. 63 ustawy o odpadach, wydanie elektroniczne, dalej: W. Radecki, Komentarz.

13 Zob. art. 63 ust. 3 ustawy o odpadach.

14 Zob. art. 63 ust. 4 ustawy o odpadach.

15 Tj. Dz. U. z 2008 r. Nr 25, poz. 150 ze zm. 
Dodać należy, że magazynowanie odpadów nie jest ich składowaniem, co pociąga za sobą dwie podstawowe konsekwencje:

1) miejsce magazynowania odpadów nie wymaga wyznaczenia w trybie przepisów o planowaniu przestrzennym ${ }^{16}$,

2) za magazynowanie odpadów nie ponosi się opłat ${ }^{17}$.

Wskazać trzeba, że ustawodawca nie wymaga załączenia do wniosku o wydanie zezwolenia na zbieranie uzgodnień wynikających z przepisów o zagospodarowaniu przestrzennym i prawa budowlanego. Nowelizacją art. 28 ustawy o odpadach, dokonaną ustawą z dnia 22 stycznia 2010 r. o zmianie ustawy o odpadach oraz niektórych innych ustaw ${ }^{18}$, uchylono ust. 10 art. 28 ustawy o odpadach, który stanowił, że „Zezwolenie na prowadzenie działalności w zakresie zbierania odpadów wydaje się po uzyskaniu pozwolenia na użytkowanie obiektu lub po zakończeniu postępowania w sprawie zgłoszenia zmiany sposobu użytkowania obiektu budowlanego lub jego części w rozumieniu ustawy z dnia 7 lipca 1994 r. - Prawo budowlane, jeżeli są wymagane". Uznano, że obowiązujące regulacje prawne zawarte $\mathrm{w}$ ustawie - Prawo budowlane dotyczace uzyskiwania pozwolenia na użytkowanie obiektu budowlanego lub zgłoszenia zmiany sposobu użytkowania obiektu lub jego części, są wystarczające $^{19}$.

Wnioskodawca musi wskazać, iż będzie przestrzegał warunków magazynowania ustalonych dla niektórych rodzajów odpadów szczegółowymi przepisami. Obejmuje to m.in.:

- oleje odpadowe, dla których warunki magazynowania określa rozporządzenie ${ }^{20}$;

16 Zob. art. 63 ust. 2 ustawy o odpadach.

17 Zob. W. Radecki, Komentar\%.

18 Dz. U. z 2010 r. Nr 28, poz. 145

19 Zob. uzasadnienie projektu ustawy z dnia 22 stycznia $2010 \mathrm{r}$.

20 Rozporządzenie Ministra Gospodarki i Pracy z dnia 4 sierpnia 2004 r. 
- odpady opakowaniowe, które magazynuje się według rozporządzenia ${ }^{21}$;

- odpady medyczne (niezakaźne), które magazynuje się zgodnie z rozporządzeniem ${ }^{22} \mathrm{~m}$.in. w odpowiednio opisanych workach i pojemnikach o odpowiednich kolorach, we właściwej temperaturze i przed przekazaniem do unieszkodliwiania nie dłużej niż 30 dni, a w niektórych przypadkach 72 godz.;

- zużyte baterie i akumulatory, które mogą być magazynowane nie dłużej niż przez 1 rok łącznie przez wszystkich kolejnych posiadaczy tych odpadów, a warunki magazynowania precyzuje art. 14 ustawy $^{23}$;

- odpady zawierające azbest, które magazynuje się zgodnie z rozporządzeniem ${ }^{24}$.

Jeśli chodzi o kierunek zagospodarowania zbieranych odpadów, wskazać należy, że odpady będą przekazane do odzysku i unieszkodliwiania oraz że odpady zebrane będą przygotowywane do transportu zgodnie $\mathrm{z}$ wymaganiami kolejnych posiadaczy. Odpady, które nie mogą być poddane odzyskowi lub unieszkodliwianiu $\mathrm{w}$ miejscu ich powstawania, zostaną, przy uwzględnieniu najlepszej dostępnej techniki lub technologii, przekazane do miejsc, w których mogą być poddane odzyskowi lub unieszkodliwianiu.

Ustawodawca wymaga również podania rodzaju magazynowanych odpadów ${ }^{25}$. W tym miejscu należy wskazać, że magazynowanie jest pojęciem węższym. Stanowi jedną z form „zbie-

21 Rozporządzenie Ministra Gospodarki i Pracy z dnia 25 października 2005 r. w sprawie szczegółowego sposobu postępowania z odpadami opakowaniowymi, Dz. U. z 2005 r. Nr 219, poz. 1858.

22 Rozporządzenie Ministra Zdrowia z dnia 30 lipca 2010 r. w sprawie szczegółowego sposobu postępowania $\mathrm{z}$ odpadami medycznymi, Dz. U. z 2010 r. Nr 139, poz. 940.

23 Ustawa z dnia 24 kwietnia 2009 r. o bateriach i akumulatorach, Dz. U. z 2009 r. Nr 79, poz. 666.

24 Rozporządzenie Ministra Gospodarki, Pracy i Polityki Społecznej z dnia 2 kwietnia 2004 r. w sprawie sposobów i warunków bezpiecznego użytkowania i usuwania wyrobów zawierających azbest, Dz. U. z 2004 r. Nr 71, poz. 649, ze zm.

25 Art. 28 ust. 4 pkt 3 ustawy o odpadach. 
rania" odpadów, która obejmuje czasowe przetrzymywanie lub gromadzenie odpadów przed ich transportem, odzyskiem lub unieszkodliwianiem (art. 3 ust. 2 pkt 3 ustawy o odpadach). Wojewódzki Sąd Administracyjny w Poznaniu w wyroku z dnia 14 marca 2012 r. $^{26}$ wskazał, że spośród czynności, które mieszczą się w zakresie „zbierania odpadów”, a więc wszystkich czynności związanych z przygotowywaniem ich do transportu do miejsc odzysku lub unieszkodliwiania, „magazynowanie” może rodzić potencjalnie największe zagrożenia z punktu widzenia ochrony środowiska. „Magazynowanie odpadów”, jako jedyne, obejmuje bowiem ich przetrzymywanie lub gromadzenie w dłuższym okresie w danym miejscu (nawet do trzech lat) ${ }^{27}$. Z tych powodów „magazynowanie odpadów” zostało przez ustawodawcę uregulowane w szczególny sposób. Sprowadza się to przede wszystkim do tego, że organ odpowiedzialny za gospodarkę odpadami w decyzji zezwalającej na zbieranie odpadów, jeżeli zezwolenie $\mathrm{w}$ danym przypadku przewiduje magazynowanie odrębnie, określa miejsce i sposób „magazynowania odpadów” (art. 63 ust. 3 w zw. z art. 28 ust. 4 pkt 3 ustawy o odpadach). Wyznaczenie specjalnych miejsc i sposobów magazynowania odpadów służy minimalizowaniu niekorzystnych oddziaływań środowiskowych, jakie ewentualnie mogą się z nim wiązać.

Mając to wszystko na względzie nie budzi wątpliwości to, że wyznaczenie miejsca magazynowania odpadów służy zagwarantowaniu należytego ich zabezpieczenia z punktu widzenia wymagań specjalistycznych, zwłaszcza wymogów ochrony środowiska. „Miejsce magazynowania odpadów” nie jest natomiast kategorią urbanistyczną, stąd nie wyznacza się go w trybie przepisów o zagospodarowaniu przestrzennym (art. 63 ust. 2 ustawy o odpadach) ${ }^{28}$.

Biorąc pod uwagę powyższe rozważania wskazać trzeba, że magazynowanie odpadów może, a nie musi być elementem decyzji na zbieranie odpadów, a tym samym podmiot, który nie chce magazynować odpadów, czyli korzystać z kwalifikowanej

26 Sygn. II Sa/Po 13/12.

27 Art. 63 ust. 3 ustawy o odpadach.

28 Zob. powołany wcześniej wyrok o sygn. II Sa/Po 13/12. 
formy zbierania, nie musi wskazywać miejsca i sposobu oraz rodzaju magazynowanych odpadów ${ }^{29}$.

W przeciwnym razie określenie miejsca i sposobu magazynowania odpadów jest obowiązkowe i polega na wskazaniu, iż odpady niebezpieczne magazynowane będą w szczelnych, oznakowanych pojemnikach dostosowanych do właściwości magazynowanych odpadów $\mathrm{w}$ pomieszczeniu posiadającym szczelną posadzkę wykonaną z odpowiedniego materiału i wyposażonym w określone materiały i sprzęt. Odpady inne niż niebezpieczne będą wysegregowane $\mathrm{w}$ pojemnikach, np. na utwardzonej, wydzielonej części placu. To miejsce powinno być wskazane w załączniku graficznym załączonym do wniosku.

Przedstawienie możliwości technicznych i organizacyjnych pozwalających należycie wykonywać działalność w zakresie zbierania odpadów rodzi wiele problemów interpretacyjnych i może stanowić przedmiot licznych wezwań organu prowadzącego postępowanie o wydanie decyzji na zbieranie odpadów żądających uzupełnienia wniosku.

Możliwości techniczne i organizacyjne odnoszące się do działań związanych z rozładunkiem, załadunkiem i magazynowaniem wiązać mogą się z faktem, iż wnioskodawca posiada specjalistyczne pojazdy i sprzęt pozwalający na rozładunek i załadunek oraz magazynowanie odpadów. Należy wymienić wyposażenie podmiotu wnioskującego o zezwolenie w sprzęt samochodowy, narzędzia, pojemniki i kontenery potrzebne do prowadzenia działalności. Warto też przedstawić elementy służące do prowadzenia działalności np. utwardzony plac manewrowy, zadaszoną wiatę magazynową, pomieszczenia socjalne, biurowe oraz urządzenia techniczne niezbędne do prowadzenia działalności magazynowania odpadów.

Z kolei działania organizacyjne związane z załadunkiem i rozładunkiem wiązać się mogą np. z przekazaniem odpadów z samochodu do samochodu czy z pojemnika do pojemnika albo z kontenera do kontenera. Wszystkie czynności odbywać się będą na wyznaczonym do tych czynności placu.

29 Art. 28 ust. 4 pkt 3 ustawy o odpadach. 
Jeżeli wnioskodawca wnosi tylko o wydanie zezwolenia, na podstawie którego będzie kontynuował dotychczasową działalność można zaznaczyć, że stan techniczno-organizacyjny nie został umniejszony od momentu wydania poprzedniej decyzji, która obecnie wygasła.

Z problemem kontynuacji działalności zbierania odpadów na terenie zorganizowanej już bazy wiąże się jeszcze jeden problem. Jeżeli np. działalność jest na konkretnej nieruchomości prowadzona od kilkunastu lat i nie wymaga zbudowania i zorganizowania od podstaw, a także powstała legalnie przed wejściem w życie przepisów nakładających obowiązek przeprowadzania ocen oddziaływania na środowisko oraz istniejąca infrastruktura służyć będzie jako kontynuacja już prowadzonej działalności w niezmienionym kształcie, wówczas nie ma obowiązku występowania o żadną z decyzji określonych w ustawie z dnia 3 października 2008 r. o udostępnianiu informacji o środowisku i jego ochronie, udziale społeczeństwa w ochronie środowiska oraz o ocenach oddziaływania na środowisko ${ }^{30}$. Takiego obowiązku nie ma tylko w sytuacji określonej powyżej przy jednoczesnym braku zamiaru podejmowania się żadnych zadań inwestycyjnych, dla których jakakolwiek z tych decyzji byłaby wymagana.

W tym miejscu trzeba wskazać na art. 60 ustawy z dnia 3 października 2008 r. - przepis zawarty w dziale zatytułowanym „Ocena oddziaływania przedsięwzięcia na środowisko oraz na obszar Natura 2000". Reguluje on m.in. problematykę przeprowadzenia oceny oddziaływania przedsięwzięcia na środowisko w przypadku realizacji planowanych przedsięwzięć. Na podstawie art. 60 wskazanej wcześniej ustawy wydano rozporządzenie Rady Ministrów z dnia 9 listopada 2010 r. w sprawie przedsięwzięć mogących znacząco oddziaływać na środowisko ${ }^{31}$, które w $\S 3$ ust. 1 pkt 81 stanowi, że do przedsięwzięć mogących potencjalnie znacząco oddziaływać na środowisko zalicza się: punkty do zbierania lub przeładunku odpadów, w tym

30 Dz. U. z 2008 r. Nr 199, poz. 1227 ze zm.; dalej cyt.: ustawa o udostępnieniu informacji.

31 Dz. U. z 2010 r. Nr 213, poz. 1397. 
złomu. Przepis ten, jak i całe rozporządzenie dotyczy inwestycji planowanej, a nie istniejącej, i to takiej, co do której inwestor ubiega się o jedną z decyzji określonych w art. 72 ust. 1 ustawy. A contrario nie jest dopuszczalne uzależnianie wydania decyzji innej niż w art. 72 ust. 1 ustawy o udostępnieniu informacji od warunku przedstawienia decyzji o środowiskowych uwarunkowaniach.

Jeśli baza służąca do zbierania odpadów istnieje i funkcjonuje od lat nie jest przedsięwzięciem planowanym, wskazane rozporządzenie nie ma zastosowania do takiego przypadku, w którym wnioskodawca występuje o wydanie decyzji na zbieranie odpadów, gdy nie planuje ani budowy punktu zbierania odpadów, ani zmiany użytkowania terenu. Stąd nie zachodzą podstawy do żądania od wnioskodawcy decyzji o środowiskowych uwarunkowaniach.

Nadto zezwolenie na zbieranie odpadów nie jest decyzją z zakresu prawa budowlanego czy zagospodarowania przestrzennego. Dodać należy, że zgodnie z tym co wcześniej podkreślono miejsce magazynowania odpadów nie wymaga wyznaczenia $\mathrm{w}$ trybie przepisów o planowaniu przestrzennym ${ }^{32}$, dlatego w tym zakresie nie wymaga się przedstawienia decyzji o warunkach zabudowy ani jakichkolwiek uzgodnień wynikających z przepisów o zagospodarowaniu przestrzennym i prawa budowlanego. Poza tym przepisy zawarte w art. 28 i 29 ustawy o odpadach nie uzależniają zezwolenia na zbieranie odpadów od takiego warunku.

Wreszcie określony w art. 28 ust. 4 pkt 6 ustawy o odpadach przewidywany okres wykonywania działalności w zakresie zbierania odpadów to element wniosku, którego realizacja będzie dokonana w momencie wskazania, że działalność będzie prowadzona przez np. następne 10 lat i podmiot wnosi o wydanie decyzji na taki okres.

Od zbierania należy odróżnić magazynowanie. Jeżeli magazynowanie następuje w czasie zbiórki w miejscu, gdzie odpady są wytwarzane i ma charakter tymczasowy - wtedy magazy-

32 Zob. art. 63 ust. 2 ustawy o odpadach. 
nowanie jest elementem procesu zbierania (art. 3 ust. 3 pkt 23 ustawy o odpadach) ${ }^{33}$.

W art. 3 ust. 3 pkt 3 ustawy o odpadach ustawodawca zawarł definicję magazynowania odpadów. Jest to „czasowe przetrzymywanie lub gromadzenie odpadów przed ich transportem, odzyskiem lub unieszkodliwianiem". Magazynowanie należy więc wiązać z procesem rozciągniętym w czasie polegającym na przetrzymywaniu lub gromadzeniu odpadów przed przewiezieniem ich do odzysku lub unieszkodliwiania. Ważnym jest tu stwierdzenie „czasowe”, co odróżnia magazynowanie od zbierania, ponieważ to ostatnie wiąże się z chwilowym np. umieszczaniem w pojemnikach czy zgromadzeniem ich w celu natychmiastowego przekazania w celach logistycznych do innego środka transportu.

Wskazać należy, że organy wydające decyzje na zbieranie odpadów niejednokrotnie zamieszczają w tych decyzjach ogólne sformułowanie, że magazynowanie ma polegać na „czasowym gromadzeniu odpadów w miejscach odpowiednio zabezpieczonych i przystosowanych do każdego rodzaju odpadu". Następnie w wyniku przeprowadzonych kontroli organ stwierdza, że np. dany podmiot na skutek nieprawidłowości związanych z magazynowaniem odpadów naruszył przepisy ustawy o odpadach, bo magazynował odpady w miejscach, które nie były odpowiednio zabezpieczone i przystosowane do magazynowania odpadów, co stanowi naruszenie np. art. 8 ustawy o odpadach zakazującego postępowania z odpadami w sposób sprzeczny z przepisami.

W takich okolicznościach wszczynana jest procedura uregulowana $\mathrm{w}$ art. 30 ust. 1-7 ustawy o odpadach. Zgodnie z tą regulacją jeżeli posiadacz odpadów, który uzyskał zezwolenie na odzysk, unieszkodliwianie, zbieranie odpadów, lub prowadzący transport odpadów, narusza przepisy ustawy lub działa niezgodnie $\mathrm{z}$ wydanym zezwoleniem, właściwy organ wzywa go do niezwłocznego zaniechania naruszeń. Jeżeli taki posiadacz odpadów, mimo wezwania, nadal narusza przepisy ustawy lub działa niezgodnie z wydanym zezwoleniem, właściwy organ

33 W. Radecki, Ustawa o odpadach. Komentarz, Wrocław 2008, s. 104. 
cofa to zezwolenie w drodze decyzji bez odszkodowania. Cofnięcie zezwolenia powoduje wstrzymanie działalności objętej tym zezwoleniem. Decyzji o cofnięciu zezwolenia właściwy organ może nadać rygor natychmiastowej wykonalności, uwzględniając potrzebę bezpiecznego dla środowiska zakończenia działalności. Posiadacz odpadów, pomimo wstrzymania prowadzonej działalności, jest obowiązany do usunięcia jej skutków na własny koszt. Postępowanie w sprawie wydania decyzji wszczyna się z urzędu. Kopię wydanej decyzji regionalny dyrektor ochrony środowiska lub starosta przekazuje marszałkowi województwa, wojewódzkiemu inspektorowi ochrony środowiska oraz wójtowi, burmistrzowi lub prezydentowi miasta właściwemu ze względu na miejsce zbierania, odzysku lub unieszkodliwiania odpadów, a w przypadku transportu odpadów - właściwemu ze względu na miejsce siedziby lub zamieszkania transportującego odpady.

Z treści tej regulacji wynika, że najpierw wydawane jest pisemne wezwanie do niezwłocznego ( $\mathrm{tj}$. bez nieuzasadnionej zwłoki) zaniechania naruszeń, a w razie bezskuteczności takiego wezwania - decyzja administracyjna cofająca zezwolenie. Zaznaczyć trzeba, że pisemne wezwanie do niezwłocznego zaniechania naruszeń jest czynnością podejmowaną $\mathrm{w}$ ramach postępowania dotyczącego cofnięcia zezwolenia. Jest to obligatoryjny element tego postępowania ${ }^{34}$. Organy dokonujące wezwania do niezwłocznego zaniechania naruszeń często popełniają błąd proceduralny polegający na braku formalnego wszczęcia postępowania dotyczącego cofnięcia zezwolenia. Co więcej, nieraz np. umarzają postępowanie w sprawie cofnięcia zezwolenia bez dokonana jego wcześniejszego wszczęcia.

Należy jeszcze wskazać, że wezwanie do niezwłocznego zaniechania naruszenia nie podlega zaskarżeniu do sądu administracyjnego. Mamy tu do czynienia z sytuacją, „[...] gdy $\mathrm{w}$ wyniku podjęcia przez organ - w ramach prowadzonej procedury - określonej czynności nie powstają skutki uzewnętrzniane poza toczące się dalej postępowanie, które skończy się dopiero

34 Zob. postanowienie WSA w Białymstoku z dnia 17 maja 2012 r. sygn. II Sa/Bk 67/12. 
wydaniem zaskarżalnej decyzji. Odmienna interpretacja oznaczałaby w istocie możliwość uruchamiania kontroli sądu administracyjnego w sposób nadmierny, co nie sprzyjałoby sprawnemu kończeniu postępowania przed organem administracji publicznej i w rzeczywistości rozmijałoby się z sensem wprowadzenia uregulowania zawartego $w$ art. $3 \S 2$ pkt 4 ustawy (vide: teza 2 i uzasadnienie postanowienia NSA z 17 maja 2007 r., II GSK 329/06, Lexnr 351117)"35.

Oprócz kwestii formalnych, które mogą wyniknąć w takim postępowaniu, mogą pojawić się również wątpliwości interpretacyjne ogólnego postanowienia decyzji w postaci określenia, że magazynowanie ma polegać na „czasowym gromadzeniu odpadów w miejscach odpowiednio zabezpieczonych i przystosowanych do każdego rodzaju odpadu". Używanie w decyzjach pojęć niedookreślonych może $\mathrm{w}$ praktyce powodować trudności w zakresie możliwości faktycznego cofnięcia udzielonego zezwolenia. Wydaje się, że organ powinien starannie określić w zezwoleniu na zbieranie odpadów to odpowiednie zabezpieczenie i przystosowanie miejsca gromadzenia każdego rodzaju odpadu. Chodzi o sprecyzowanie i uszczegółowienie co konkretny podmiot może dokonywać $\mathrm{w}$ ramach posiadanego zezwolenia i w jaki sposób powinien gospodarować odpadami. Tym uszczegółowieniem może być np. postanowienie, iż „Powierzchnie komunikacyjne przy obiektach do przechowywania odpadów oraz place przeładunkowe i drogi wewnętrzne mają być utwardzone, uszczelnione przed przeciekami wód opadowych do gruntu, a magazynowane odpady, w zależności od klasyfikacji tych odpadów - (niebezpieczne lub inne niż niebezpieczne), zapakowane muszą być na wydzielonej części bazy (załącznik graficzny do decyzji) w mocnych workach foliowych, szczelnych kontenerach i innych pojemnikach uniemożliwiających skażenie środowiska". Oczywiście nie można twierdzić, ze proponowane rozwiązanie wyeliminuje $\mathrm{w}$ całości wątpliwości interpretacyjne, ale na pewno zmniejszy ich ilość, a co za tym idzie ograniczy trudności w prowadzeniu postępowania o cof-

\footnotetext{
35 Ibidem.
} 
nięcie zezwolenia oraz zmniejszy nadużycia podmiotów realizujących postanowienia decyzji na zbieranie odpadów.

Omówione zagadnienia pokazują, że stosowanie w praktyce przepisów ustawy o odpadach powoduje wiele wątpliwości. Podstawowe czynności w zakresie gospodarowania odpadami, jakimi są zbieranie i magazynowanie są niejednoznacznie rozumiane przez organy i przedsiębiorców. To z kolei powoduje trudności w postępowaniu o wydanie zezwolenia na zbieranie i następnie później w razie ewentualnej konieczności prowadzenia postępowania o cofnięcie zezwolenia pojawiają się wątpliwości interpretacyjne, które mogą rodzić nadużycia przedsiębiorców, jak i powodować błędne decyzje organów.

\section{BIBLIOGRAFIA}

Górski M., Zbieranie i transport odpadów, „Przegląd Komunalny” 2008, nr 2.

Jendrośka J., Jerzmański J. (red.). Ustawa o odpadach. Komentarz, Wrocław 2001.

Radecki W., Komentarz do art. 63 ustawy o odpadach, wydanie elektroniczne.

Radecki W., Ustawa o odpadach. Komentarz, Warszawa 2008.

Kontakt e-mail:

karolinaszuma@gmail.com 